\title{
MEDICINE AND THE LAW \\ Provisions for consent by children to medical treatment and surgical operations, and duties to report child and aged persons abuse: 1 April 2010
}

\author{
David McQuoid Mason
}

\begin{abstract}
The remaining sections of the Children's Act ${ }^{1}$ and the Children's Amendment $\mathrm{Act}^{2}$ came into effect on 1 April 2010, thus completely repealing the Child Care Act. ${ }^{3,4}$ The provisions of the Children's Act dealing with the capacity of children to consent to HIV testing ${ }^{5}$ and to access contraceptives ${ }^{6}$ have been in effect since 1 July 2007. ${ }^{7}$ The Children's Act now allows sufficiently mature children of 12 years of age to consent to medical treatment, and to consent to surgical operations with the assistance of their parent or guardian. ${ }^{8}$ The provisions allowing consent to termination of pregnancy by girls of any age in the Choice on Termination of Pregnancy Act ${ }^{9}$ are not affected by the Children's Act. ${ }^{10}$

On the same date, the Children's Amendment Act ${ }^{11}$ and Older Persons Act ${ }^{12}$ came into effect. The Children's Amendment Act replaces the child abuse reporting duties in the Child Care $\mathrm{Act}^{3}$ and the Prevention of Family Violence Act, ${ }^{13}$ both of which were repealed when the Children's Amendment Act came into effect. ${ }^{14}$ The Older Persons $\mathrm{Act}^{12}$ replaces the duty to report abuse and neglect of aged persons in the Aged Persons Act ${ }^{15}$ (as amended by the Aged Persons Amendment Act $)^{16}$ which was repealed when the Older Persons Act came into effect. ${ }^{17}$
\end{abstract}

\section{Consent to medical treatment and surgical operations by children}

The repealed Child Care $\mathrm{Act}^{3}$ provided that children over the age of 14 years could consent to medical treatment, and minors over the age of 18 years could consent to surgical operations. The provision that children of 18 years or older could consent to surgical operations became redundant when the Children's Act lowered the age of majority from 21 years to 18 years in July $2007 .^{18}$

The Children's Act states that children may consent to medical treatment of themselves or their children if they are 12 years of age or more and of sufficient maturity and with the mental capacity to understand the benefits, risks, and social and other implications of such treatment. ${ }^{19}$ Regarding surgical operations, children of 12 years or older who are sufficiently mature and mentally capable may consent to surgical operations with the assistance of their parent or guardian. ${ }^{20}$

The requirements of 'sufficient maturity' and 'mental capacity' mean that age alone does not determine whether children may consent to medical treatment - they must still be sufficiently mature to give informed consent. If the patient cannot give such consent, the doctor must rely on the consent of the parent or guardian or other legally competent person to satisfy the legal requirement of consent, which is required to allow the child to participate in the decision-

David McQuoid-Mason is Professor of Law at the Centre for SocioLegal Studies, University of KwaZulu-Natal, Durban, and publishes and teaches in medical law. making process in terms of the National Health Act. ${ }^{21}$ However, the legal consent must be provided by the parent or guardian concerned or other legally competent person.

\section{Consent on behalf of children without legal capacity to give consent}

The Children's Act provides that if a child is under 12 years of age, or over the age of 12 years but insufficiently mature or unable to understand the benefits, risks and social implications of the medical treatment or surgical operation, the following may consent to medical treatment or surgical operations: (i) the parent or guardian; ${ }^{22}$ (ii) in emergencies, the superintendent of a hospital (or the person in charge of the hospital in the absence of superintendent); $;^{23}$ (iii) if the parent or guardian unreasonably refuses to give consent or assist, is incapable of doing so, cannot be readily traced or is deceased, the Minister of Social Development; ${ }^{24}$ and (iv) in all instances where another person who may give consent refuses or is unable to give such consent, a High Court or a children's court. ${ }^{25}$

In terms of the Children's Act, a parent or guardian of a child may not: (i) refuse to assist a child who consents to a surgical procedure, or (ii) withhold consent for medical treatment or a surgical operation solely on the grounds of religious or other beliefs - unless such parent or guardian can show that there is a medically accepted alternative to the medical treatment or surgical operation concerned. ${ }^{26}$

\section{Refusal of consent to medical treatment or surgical operations by children}

A person who has legal capacity to consent to medical treatment or surgical operations can also refuse such consent. A health care provider must inform patients of their right to refuse health services and explain the implications, risks and obligations of such refusal. ${ }^{27}$ However, the High Court as the upper guardian of all minors may overrule a refusal to consent by children if it is in 'the best interests' of a child patient - but is likely to use this power sparingly. The Minister of Social Development can consent to medical treatment or a surgical operation where the child unreasonably refuses to give consent. ${ }^{28}$

\section{Compulsory duty to report abused or neglected children}

The Children's Amendment Act ${ }^{11}$ compels medical practitioners and other health care providers to report abused or neglected children to a designated child protection organisation, the provincial department of social development or a police official. ${ }^{29}$ Health care providers include dentists, homeopaths, medical practitioners, midwives, ministers of religion, nurses, occupational therapists, physiotherapists, psychologists, speech therapists, traditional health practitioners, and members of staff or volunteer workers at partial care facilities, drop-in centres or child and youth care centres who on reasonable grounds conclude that a child has been physically injured, sexually abused or deliberately neglected..$^{29}$

If the report of abuse is substantiated on the prescribed form, made in good faith, and reported to the relevant designated child protection organisation, the provincial department of social development or a police official, the person making it cannot be held legally liable. ${ }^{30}$ 


\section{Discretionary authority for anyone to report children in need of care and protection}

Any person who on reasonable grounds believes that a child is in need of care and protection may report that belief to the provincial designated child protection organisation or a police official. ${ }^{31}$ The reporting person has a degree of discretion about whether or not to make a report. The report must be substantiated in the prescribed manner and, if made in good faith, the person making it is not liable to a civil action. ${ }^{30}$ The provision applies to anyone - not only the above listed persons who are legally obliged to report child abuse or neglect.

\section{Compulsory duty on persons involved with older persons in a professional capacity to report older persons in need of care and protection or who have been abused}

The Older Persons Act ${ }^{12}$ provides that any person who is professionally involved with an older person (a male of 65 years of age or older or a female of 60 years of age or older) ${ }^{32}$ and who on personal observation concludes that the older person needs care and protection, must report this to the Director-General (DG) of Social Sevelopment. ${ }^{33}$ This applies to anyone, including doctors and other health care providers who treat patients.

Anyone who suspects that an older person has been abused or suffers from an abuse-related injury must immediately notify the DG of Social Development or a police official of this suspicion, ${ }^{34}$ and is not legally liable if such notification is given in good faith. ${ }^{35}$ Persons who fail to notify the DG or a police official of their suspicion that an older person has been abused or suffers from an abuse-related injury are guilty of an offence. ${ }^{36}$

\section{Discretionary authority for persons, other than those involved with older persons in a professional capacity, to report older persons in need of care and protection}

Discretionary reporting authority is given to anyone, other than those involved with an older person in a professional capacity, who is of the opinion that an older person is in need of care and protection. ${ }^{12}$ Such a report may be made to a social worker. ${ }^{37}$ A person who makes a report in good faith will not be legally liable, and is protected by the common law defenses of statutory authority or qualified privilege. ${ }^{38}$ Provided that the report is relevant and not based on improper motive, malice or spite, the person making the report will not be legally liable for defamation or an invasion of privacy.
1. Children's Act No. 38 of 2005.

. Children's Amendment Act 41 of 2007.

Child Care Act No. 74 of 1983.

4. Government Notice R12 in Government Gazette 330761 April 2010

5. Section 130 of the Children's Act No.38 of 2005.

6. Section 134 of the Children's Act No. 38 of 2005

7. McQuoid-Mason DJ. The effect of the new Children's Act on consent to HIV testing and access to contraceptives by children. S Afr Med J 2007; 97: 12521253

8. Section 129(2) and (3) of the Children's Act No. 38 of 2005.

9. Section 5(2) and (3) of the Choice on Termination of Pregnancy Act No. 92 of 1996.

10. Section 129(1) of the Children's Act No. 38 of 2005.

11. Children's Amendment Act No. 41 of 2007

12. Older Persons Act No. 13 of 2006.

13. Prevention of Family Violence Act No. 133 of 1993.

14. Government Notice R13 in Government Gazette 330761 April 2010.

15. Aged Persons Act 81 pf 1967

16. Aged Persons Amendment Act No.100 of 1998

17. Government Notice R11 in Government Gazette 330761 April 2010.

18. Section 17 of the Children's Act No. 38 of 2005.

19. Section 129(2) of the Children's Act No. 38 of 2005.

20. Section 129(3) of the Children's Act No. 38 of 2005

21. Section 8(1) of the National Health Act No. 61 of 2005.

22. Section 129(4) of the Children's Act No. 38 of 2005.

23. Section 129(6) of the Children's Act No. 38 of 2005.

24. Section 129(7) of the Children's Act No. 38 of 2005.

25. Section 129(9) of the Children's Act No. 38 of 2005.

26. Section 129(10) of the Children's Act No. 38 of 2005

27. Section 6(1) of the National Health Act No. 61 of 2003

28. Section 129(8) of the Children's Act No. 38 of 2005.

29. Section 110(1) of the Children's Amendment Act No. 41 of 2007.

30. Section 110(3) of the Children's Amendment Act No. 41 of 2007

31. Section 110(2) of of the Children's Amendment Act No. 41 of 2007.

32. Section 1 of the Older Persons Act No. 13 of 2006.

33. Section 25(1) of the Older Persons Act No. 13 of 2006

34. Section 26(1) of the Older Persons Act No. 13 of 2006.

35. Section 26(2) of the Older Persons Act No. 13 of 2006.

36. Section 26(3) of the Older Persons Act No. 13 of 2006

37. Section 25(2) of the Older Persons Act No. 13 of 2006

38. Dada MA, McQuoid-Mason DJ. Introduction to Medico-Legal Practice. Durban: Butterworths, 2001: 20-21 